\title{
Improving Auditor Performance Through A Spirituality Workplace Based on Tri Hita Karana, Hardiness Personality and Role Stress
}

\author{
Mertyani Sari Dewi1ํㅜ, Made Dwi Ferayani², Gusti Putu Eka Kusuma ${ }^{3}$
}

1,2,3 Sekolah Tinggi Ilmu Ekonomi Satya Dharma

\section{A R T I C L E I N F O \\ Article history: \\ Received 18 May 2020 \\ Received in revised form \\ 5 June 2020 \\ Accepted 18 July 2020 \\ Available online 29 August \\ 2020}

Keywords:

Performance, Workplace,

Hardiness, Role Stress

\section{A B S T RA C T}

This research is motivated by the importance of auditor performance in determining the performance of quality public accounting firm (KAP). The ability of auditors in a professional manner in using audit techniques and procedures to improve audit quality has an effect on the resulting performance. The study was conducted to provide empirical evidence regarding efforts to improve auditor performance through Tri Hita Karana-based workplace spirituality, hardiness personality and role stress in Public Accounting Firms (KAP) throughout Bali Province. The population in this study were all KAP auditors in Bali Province who were listed in the Directory published by the Indonesian Institute of Certified Public Accountants (IAPI) in 2020. The sampling technique was purposive sampling with the criteria used by the sample, including the auditors working in KAP throughout Bali Province. is still actively operating and has a minimum of 1 year of service or audit experience. This research was tested using a variance based structural equation model (Structural Equation Modeling-SEM) or Component based SEM with the SmartPLS 3.0 analysis tool. The test results show empirical evidence that Tri Hita Karana-based workplace spirituality weakens the effect of role conflict on auditors' performance, but Tri Hita Karana-based workplace spirituality does not moderate the effect of role ambiguity and role overload on auditor performance, while hardiness personality cannot moderate the effect of role conflict on performance. auditors, but hardiness personality weakens role ambiguity and role overload on auditor performance.

Copyright (C) Universitas Pendidikan Ganesha. All rights reserved.

\footnotetext{
*Corresponding author.

E-mail addresses: mertyanisaridewi@gmail.com ${ }^{1}$ (Mertyani Sari Dewi), dwiferayani@gmail.com² (Made Dwi Ferayani), ekakusuma700@gmail.com³ (Gusti Putu Eka Kusuma)
} 


\section{Introduction}

The role of auditors to improve the quality and credibility of an entity's financial statements is very important in today's business developments. Auditors are required to be able to produce good performance because this will directly impact the performance and image of the company where the auditor works. Role stress has the potential to cause a decrease in one's performance. Role stress arises due to conditions that are often faced by auditors, namely role conflict, role ambiguity and role overload. In this advanced era, the needs of human life are increasing. Along with this, there are more and more companies that aim to produce goods and services to meet human needs. To become a healthy company, financial reports must be audited by a competent public accountant, so that later the audit results will not have a negative impact on the company (Suariana et al., 2014).

The role theory expressed by (Kahn et al., 1964) revealed that when the behavior expected by a role sender contains conflict, is inconsistent and unclear, the role incumbent has the potential to experience stress, depression, and decreased motivation and performance. Previous research still obtained inconsistent results, this could be because there are other variables that affect the performance of auditors besides role stress.

Auditor performance is a manifestation of work done in achieving better or more prominent work results towards achieving organizational goals. Goldwasser in (Hanif, 2013) suggests that the achievement of better auditor performance must be in accordance with certain standards and time periods, namely: First, work quality, namely the quality of completing work by working based on all abilities and skills and knowledge possessed by auditors. Second, the quantity of work, namely the results of work that can be completed with the target that is the responsibility of the auditor's job and the ability to utilize work support facilities and infrastructure. Third, punctuality, namely the timeliness available to complete work.

The intense competition among auditors and the development of the profession requires auditors to always improve their performance, so that they are believed to be able to become quality auditors and be able to produce high quality audit products. In connection with the auditor's responsibility in detecting fraud that occurs in financial reports, the Auditing Standards Board (ASB) issued a Statement on Auditing Standards (SAS) No 82.This SAS No. 82 was issued to improve auditor performance by adding and clarifying operational guidelines for auditors. in considering the material fraud that occurs.

This research is motivated by the importance of auditor performance in determining the performance of quality public accounting firm (KAP). The ability of auditors in a professional manner in using audit techniques and procedures to improve audit quality has an effect on the resulting performance. The role of auditors is very important in helping to improve and improve the performance of public accountants to become increasingly qualified. Auditors must be able to control themselves in seeing an event and be able to face various challenges and threats in order to better maintain professional ethics.

Auditor performance is defined as the work achieved by the auditor in carrying out his duties in accordance with the responsibilities assigned to the auditor. The results of this work will be a benchmark that can be used to determine whether the work done has gone well or vice versa (Fanani et al., 2008). In connection with research on the effect of role stress on auditor performance, role theory is one of the theories used to analyze the data in this study. This theory was put forward by (Kahn et al., 1964). Role stress can result in decreased motivation to do their job well. This decrease in work motivation will ultimately affect the performance and decision of the recipient of the role to leave the organization or company (Anggraini, 2008). According to (Kahn et al., 1964), role pressure at work arises because there are two conditions that are often faced by auditors, namely role ambiguity and role conflict.

In fact, the causes of poor auditor performance and the occurrence of accounting scandals are due to the failure to carry out important audit procedures or to evaluate audit evidence properly, as well as the inherent limitations of the financial statement audit itself (Singh, 1998). In addition, the decline in auditor performance can also be influenced by role stress experienced by auditors (Yustrianthe, 2008).

Workplace spirituality is seen as a recognition of individual spiritual values that occur in an organizational context (Ashmos \& Duchon, 2000). Spirituality at work involves finding one's ultimate goal in life, developing strong work-related co-workers' relationships, and having consistency or alignment between a person's core beliefs and their organizational values (Czaplewski, 2003). Based on the P-O Fit theory, where the fit between organizational values and individual values (Kristof, 1996) will increase job satisfaction and performance and will reduce employee work stress (Mount \& Muchinsky, 1978). The application of workplace spirituality raises a more positive employee perception of the organization so that employees get change and achieve better adjustments through work with higher satisfaction (Martins 
et al. 2012). Employees with a good level of spirituality in the workplace will have good performance as well, (Rolland et al., 2015) Spirituality is an attempt to educate people how to deal with themselves, with other people, and other beings besides humans, as well as to relate to God, or to explore in the necessary paths. Spirituality strengthens what people do and will be strengthened by them in turn. The Tri Hita Karana culture is a philosophy which is also the concept of life and the cultural system of the people in Bali. The concept of life that emphasizes the principles of togetherness, harmony, and balance between economic goals, environmental and cultural preservation, aesthetics and spirituality (Tenaya, 2007).

Personality is one of the most important factors to pay attention to in an organization so that someone can improve their performance so that it will have an effect on improving organizational performance (Putra \& Ariyanto, 2012). Hardiness is one of the personality characteristics that individuals have in dealing with stressful situations. Individuals who have high hardiness personalities will have strong psychological resilience because these individuals will be able to deal with pressure by changing negative stressors into positive challenges (Istiningtyas, 2013). Hardiness personality characteristics are characterized by a strong commitment to the individual which involves the ability to control unpleasant events and give positive meanings to events experienced by individuals as natural challenges so that individuals are more resistant to stress (Amiruddin \& Ambarini, 2014).

Several previous studies have examined the effect of role stress on auditor performance. Research conducted by (Fisher, 2001) found that role conflict and role ambiguity had a positive effect on auditor performance. (Agustina, 2009) found that role conflict, role ambiguity, and role overload simultaneously had an effect on auditor performance. Partially role conflict, role ambiguity, and role overload have a negative effect on auditor performance, and there is research that states that workplace spirituality can weaken role stress on auditor performance (Ary, 2017).

In previous studies there were still inconsistencies in research results. This can be due to other variables that affect auditor performance. A person's performance can be affected by many factors. One of them is the personality characteristics of the individual (Widhiastuti, 2002). Besides that, it can also be seen from the spirituality factor at work which is very effective in directing humans in dealing with life problems among them at work, especially when employees experience a decrease in commitment, job satisfaction and performance (Budiono et al., 2014). Based on the cognitive theory put forward by Albert Bandura, it is stated that every action that a person takes will be influenced by personal characteristics and one of them is personality. Individuals with high spirituality are more able to manage the role stress that individuals receive with spiritual practice and spiritual awareness, based on the Tri Hita Karana (THK) which is the concept of harmonizing relationships that are always maintained by the Balinese Hindu community, including: Parahyangan (human relationship with God), Pawongan (inter-human relations), and Palemahan (human relationship with the environment) which is sourced from the Hindu holy book Baghawad Gita, naps and tawakul (based on Islamic science), meditation and also worship. This spiritual practice and spiritual thought normalizes the nervous system, reduces heart rate, lowers anxiety levels, increases feelings of spiritual, social and emotional well-being (Hassan et al., 2015). Spirituality personality puts forward the formation of spiritual values in individuals and forms an awareness of life including the stress they experience. However, low personal spirituality will lose their spiritual awareness so that the spiritual practice that is carried out is still unable to carry out stress management properly (Piedmont, 1999). According to Charles Schreiber, the success of a person's life is determined by formal education only $15 \%$, while $85 \%$ is determined by their personality or mental attitude (Olivia, 2014). Workplace spirituality contains the constructs of compassion, mindfulness, meaningful work, and transcendence (Duchon \& Petchsawanga, 2009). This construct makes workplace spirituality a tool for dealing with stress (Dhang, 2014). Auditors who experience role conflicts, the longer their independence will be threatened and experience stress at work, but by interpreting their work (meaningful work), the auditor will understand the objectives of the audit profession.

Based on the explanation, this study aims to provide the empirical evidence regarding efforts to improve auditor performance through Tri Hita Karana-based workplace spirituality, hardiness personality and role stress in Public Accounting Firms (KAP) throughout Bali Province.

\section{Methods}

This study was a descriptive quantitative research. This research is located in all KAP in Bali Province with a total of 12 KAP. In accordance with the research objectives, a framework of thought, concept, and hypothesis is formulated so that it can be made according to the research design. Research design has a very important role in the success of a study, because this research design is the reference for conducting research. 
As for the population in this study are all auditors of the Public Accounting Firm in Bali Province who are listed in the Directory published by the Indonesian Institute of Certified Public Accountants (IAPI) in 2020. The population of this study is 119. The sampling method used in this study is the nonprobability method. sampling. The sampling technique used in this study was purposive sampling, with the criteria of auditors being sampled, among others, (1) As an auditor who works in Public Accounting Firms in Bali Province, (2) Has a minimum working period or audit experience of 1 year with the consideration that auditors who have worked for at least 1 year at KAP have sufficient understanding of the given audit assignments and are able to adapt to the work environment and have obtained duties as junior auditors. Based on the calculation results of the determination of the number of research samples, the number of auditors used as the research sample was 92 people.

In this study, the moderating variables are THK-based Workplace Spiritulity and Hardiness Personality, where THK-based Workplace Spiritulity is measured by nine indicators and Hardiness Personality is measured by fourteen indicators.

The collected data was tabulated based on each category and statistical analysis was performed. The analysis technique used in this study is a Variance-based Structural Equation Modeling (SEM) model or Component based SEM, which is known as Partial Least Square (PLS) Visual version 3.0.

\section{Results and Discussions}

\section{Assess the Outer Model or Measurement Model}

In testing the validity of the outer model, there are two factors that will be observed in the validity test, namely the loading factor value (convergent validity) and the cross loading value (discriminant validity). Convergent validity measures the correlation between the question items and the constructs in the study. Individual reflexive measures are said to be correlated if more than 0.7 with the construct to be measured. However, for research in the early stages of developing a measurement scale the loading factor value of 0.6 is considered sufficient (Ghozali, 2008). At the initial stage, data testing was carried out to determine the level of accuracy of the indicators in explaining exogenous constructs in the model using the loading factor. Based on the following research model path diagram, the results are shown as in Figure 1.

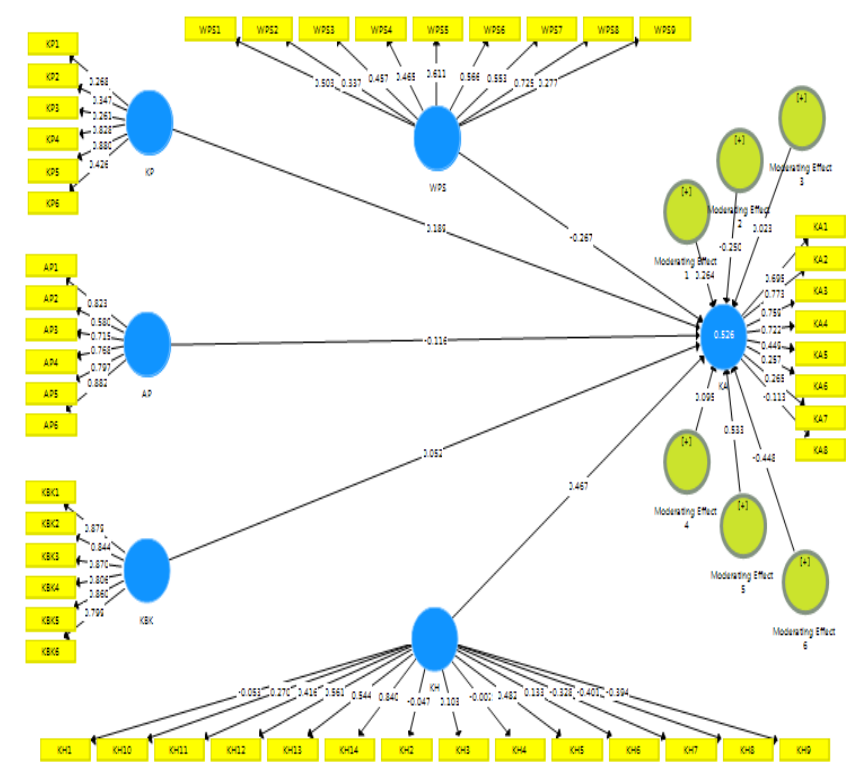

Figure 1. The Value of Loading Factor using the PLS Path Diagram

Based on the picture above, the loading factor value shows the results that meet the convergent validity because all loading factors are $>0.6$. Thus, it can be concluded that the convergent validity of all constructs is valid.

To strengthen the valid statement of the construct of this study, researchers also used the Average Variance Extracted (AVE) method. a good construct requires that the AVE value must be above 0.50. The AVE test results are described as follows: 
Table 1. Average Variance Extracted (AVE) Value

\begin{tabular}{lc}
\hline Moderating Effect 1 & 1.000 \\
Moderating Effect 2 & 1.000 \\
Moderating Effect 3 & 1.000 \\
Moderating Effect 4 & 1.000 \\
Moderating Effect 5 & 1.000 \\
Moderating Effect 6 & 1.000 \\
\hline
\end{tabular}

Table 1 provides AVE values above 0.5 for all constructs contained in the research model. So it can be concluded that the construct in this study is valid.

In this study, the moderating variables are THK-based Workplace Spiritulity and Hardiness Personality, where THK-based Workplace Spiritulity is measured by nine indicators and Hardiness Personality is measured by fourteen indicators.

The construct is said to have high reliability if the Composite Reliability value is above 0.70 and the Cronbachs Alpha value is above 0.60 (Ghozali, 2008). Table 2 presents the Composite Reliability and Cronbachs Alpha values for all variables.

Table 2. Value of Composite Reliability and Cronbach Alpha

\begin{tabular}{ccc}
\hline & Cronbach's Alpha & Composite Reliability \\
\hline Moderating Effect 1 & 1.000 & 1.000 \\
Moderating Effect 2 & 1.000 & 1.000 \\
Moderating Effect 3 & 1.000 & 1.000 \\
Moderating Effect 4 & 1.000 & 1.000 \\
Moderating Effect 5 & 1.000 & 1.000 \\
Moderating Effect 6 & 1.000 & 1.000 \\
\hline
\end{tabular}

Source: Output SmartPLS 3.0

Table 2 above shows that all constructs in this study produce a Composite Reliability value above 0.70 and a Cronbachs Alpha value above 0.60 . It can be concluded that the construct in this study is reliable.

In assessing the model with PLS, it starts by looking at the R-square for each dependent latent variable (Ghozali, 2013). Table 3 is the estimation result of R-square using Smart PLS.

Table 3. R-Square Value

\begin{tabular}{lcc}
\hline & R Square & R Square Adjusted \\
\hline Auditor Performance & 0.526 & 0.461 \\
\hline & & Source: Output Smart PLS 3.0
\end{tabular}

Based on the data of the coefficient of determination above, it is known that the R-Square value of Audiotr Performance is 0.526 , the magnitude of the R-Square number is 0.461 equal to $46.1 \%$ can be explained by four construct variables.

The basis used in testing the hypothesis is the value contained in the output result forinner weight. Table 4 provides the estimated output for structural model testing.

Table 4. Result for Inner Weight

\begin{tabular}{|c|c|c|c|c|c|c|}
\hline & & $\begin{array}{l}\text { Original } \\
\text { Sample (0) }\end{array}$ & $\begin{array}{l}\text { Sample } \\
\text { Mean (M) }\end{array}$ & $\begin{array}{l}\text { Standard } \\
\text { Deviation } \\
\text { (STDEV) }\end{array}$ & $\begin{array}{l}T \quad \text { Statistics } \\
(|O / S T D E V|)\end{array}$ & $\begin{array}{l}P \\
\text { Valu } \\
\text { es }\end{array}$ \\
\hline $\begin{array}{l}\text { Moderating Effect } 1 \\
\text { Auditor Performance }\end{array}$ & $->$ & 0.264 & 0.167 & 0.129 & 2.053 & 0.040 \\
\hline $\begin{array}{l}\text { Moderating Effect } 2 \\
\text { Auditor Performance }\end{array}$ & $->$ & -0.250 & -0.227 & 0.190 & 1.314 & 0.189 \\
\hline Moderating Effect 3 & $->$ & 0.023 & 0.177 & 0.152 & 0.151 & 0.880 \\
\hline
\end{tabular}


Auditor Performance

Moderating Effect 4 ->

Auditor Performance 0.095

0.150

0.119

0.796

0.426

Moderating Effect $5 \rightarrow 0.533$

0.300

0.249

2.142

0.032

Moderating Effect 6 ->

Auditor Performance

$-0.448$

$-0.241$

0.204

2.193

0.029

Source: Output Smart PLS 3.0

\section{Discussion}

THK-Based Workplace Spirituality Weakens the Influence of Role Conflict on Auditor Performance in Public Accounting Firms in Bali Province.

The first hypothesis (H1) states that THK-based workplace spirituality weakens the influence of role conflict in efforts to increase auditor work in Public Accounting Firms throughout Bali Province. The output results show that the coefficient of interaction between THK-based workpalce and role conflict is 0.264 with a $t$ of 2.053 , which is greater than the t table (1.661). The results of the research analysis showed that H1 was accepted. This means THK-based workplace spirituality weakens the effect of role conflict on auditor performance.

Auditors who experience role conflicts, will experience stress due to the pressure they experience, feel that their work is not attractive, so that they can reduce their work performance (Nazli \& Nor, 2011). Individuals who have spiritual awareness will understand more about their work. Someone who can interpret their work well, has a good psychological and quality desired by the organization, can focus on work, see work as something more important (Giacalone et al., 2008). Understanding the meaning of work and seeing work as a vocation will also enable individuals to achieve the deepest possible levels of performance and psychological success (Chatterjee \& Singhal, 2006).

Role conflict is the impact of individuals playing conflicting roles. However, interpreting their work properly will form an awareness that the perceived role conflict is the demands of their work, so that this makes individuals more able to manage the right time, when they should carry out a certain role. In addition, organizational support is also an important factor in reducing the influence of role conflicts in the organization. An environment that prioritizes the spiritual aspect by creating a feeling of attachment between oneself and others, feeling sympathy and, the desire to relieve the suffering of others, can form a more positive environmental condition. This can be in the form of policies to help each other between colleagues, to be good supervisors and to be able to support their subordinates, as well as other support from colleagues in the form of providing advice and other forms of sympathy (Twigg \& Parayitam, 2006).

\section{THK-Based Workplace Spirituality Weakens the Influence of Role Ambiguity on Auditor} Performance in Public Accounting Firms in Bali Province.

The second hypothesis (H2) states that THK-based workplace spirituality weakens the effect of role ambiguity on the performance of auditors in public accounting firms in Bali Province. The output results show that the THK-based workpalce spirituality interaction coefficient with role ambiguity is -0.250 with a $t$ of 1.314 where this value is smaller than the $t$ table (1.661). The results of the research analysis showed that $\mathrm{H} 2$ was rejected. this means that THK-based workplace spirituality cannot moderate the effect of role ambiguity on auditor performance. This means, facilitating individuals with a THK-based workplace spirituality (provision of facilities for individual personal fulfillment), whether good or bad, cannot guarantee to strengthen or weaken the influence of role ambiguity in an effort to improve auditor performance.

Stress is generally considered as the presence of negative thoughts (sad, depressed, lazy). Spiritual or religious practices can indeed provide sufficient energy to deal with stress (Hassan et al., 2015). However, spiritual or religious practice that is not carried out seriously, correctly and with enthusiasm, will not provide maximum benefit. Lack of concentration while doing spiritual practice will not generate the spiritual awareness needed to create deep understanding (Heaton et al., 2004; Hassan et al., 2015). Workplace spirituality at the individual level leads to the formation of spiritual awareness that makes individuals have several attitudes such as pleasure at work, giving new energy every time they work, and being able to interpret work well (Heaton et al., 2004). Where role ambiguity is ambiguity / uncertainty related to job tasks and expectations, lack of appropriate work behavior guidelines, and unclear behavior outcomes (Rizzo et al., 1970). Employees who experience role ambiguity will be confused about their duties and the goals / targets of their work. The employee will continue to complete his work but will be accompanied by stress due to the ambiguity. 
When auditors experience ambiguity / uncertainty related to job duties and expectations, their work will be felt longer and panic when expectations for results do not match reality. The lack of selfcontrol over this made the auditors stressed and the role of THK-based Workplace Spirituality was not felt by the auditors. Auditors who experience uncertainty / uncertainty related to work tasks sometimes require a lot of time, effort and thought to complete their duties. ambiguity / uncertainty regarding these work tasks creates feelings of anxiety and stress, hinders work, and ultimately reduces performance.

\section{THK-Based Workplace Spirituality Weakens the Effect of Role Overload on Auditor Performance in Public Accounting Firms in Bali Province.}

The third hypothesis (H3) states that THK-based Workplace Spirituality weakens the effect of excess workload on auditors' performance in public accounting firms in Bali Province. The output results show that the THK-based workpalce spirituality interaction coefficient with role overload is 0.023 with $t$ of 0.151 where the value is smaller than the $t$ table (1.661). The results of the research analysis indicate that $\mathrm{H} 3$ is rejected, this means that THK-based workplace spirituality cannot moderate the effect of role overload on auditor performance. This means, facilitating individuals with a THK-based workplace spirituality (provision of facilities for individual personal fulfillment), whether good or bad, cannot guarantee to strengthen or weaken the influence of role overload in an effort to improve auditor performance.

Some literature suggests workplace spirituality can be a stress management tool (Deshmukh \& Doraiswamy, 2015; Hassan et al., 2015). Stress is generally considered as the presence of negative thoughts (sad, depressed, lazy). Spiritual or religious practices can indeed provide sufficient energy to deal with stress (Hassan et al., 2015). However, spiritual or religious practice that is not carried out seriously, correctly and with enthusiasm, will not provide maximum benefit. Lack of concentration while doing spiritual practice will not generate the spiritual awareness needed to create deep understanding (Heaton et al., 2004; Hassan et al., 2015).

Research by (Deshmukh \& Doraiswamy, 2015) also states that the influence of spirituality can reduce stress. When there is harmony and harmony between individual and organizational values it will lead to lower stress levels. Organizations with a high level of spirituality are characterized by a culture of hope, social support, and a belief system, enabling employees to be more adaptable to work and more immune to stress (Deshmukh \& Doraiswamy, 2015). The research explicitly states that a high spiritual culture will lead the organization to a culture of hope, high social support and a belief system. This leads the individual to lower stress levels by reaching out to family and friends who need help.

Workplace spirituality is said to provide a vertical and horizontal spiritual dimension to help achieve the direction and purpose of life (Altaf \& Awan, 2011). Workplace spirituality also helps individuals to communicate better and communicate with others. This increased communication can increase confidence and overcome excessive work (Milliman et al., 2008). One aspect of workplace spirituality (organizational level) is the provision of facilities for individual personal fulfillment. This can include career development and training which enable individuals to perform better in different situations, especially in overcoming role conflicts and role ambiguities. Facilitating individuals with Workplace Spirituality helps individuals develop affection for the organization and will retain those individuals, as well as lowering costs for recruiting and rehiring efficient staff (Altaf \& Awan, 2011).

However, other research says workplace spirituality does not effectively reduce stress. The use of spirituality as stress management in family members who are waiting for the operation process experiences higher levels of stress and anxiety (Zinnbauer et al., 1998). These results are concluded as a result of the level of stress experienced by individuals (Seidlitz \& Youngmee, 2002; Bell et al., 2012). High stress levels make individuals no longer consider their spiritual awareness and are more concerned with results in accordance with the expectations they receive. If these results do not match the expectations they receive, it will cause anxiety. High anxiety will make a person panic quickly and at that time his spiritual awareness no longer plays a role in stress management (Seidlitz \& Youngmee, 2002).

Respondents' answers indicate that the auditor is classified as experiencing a high work overload. The high workload overload makes the auditor's spiritual awareness unable to carry out its function as a stress management (coping) tool (Seidlitz \& Youngmee, 2002; Bell et al., 2012). Excess workload experienced by auditors causes auditors to have less time to meet expectations in living their personal and social lives. Auditors are more focused on completing the assigned task and ignoring their spiritual value by not prioritizing social relations and the meaning of their work. When you are overloaded, your work is felt to be unattractive for a long time, you feel anxious and panic when your expectations for results don't match reality. The lack of self-control over this made the auditors stressed and the role of THK-based Workplace Spirituality was not felt by the auditors. Auditors who are overloaded sometimes need a lot of 
time, effort and thought to complete their tasks. This overload of work creates feelings of anxiety and stress, hinders work, and ultimately reduces performance (Hellhammer et al., 2004).

\section{Hardiness Personality Weakens the Effect of Role Conflict on Auditor Performance in Public Accounting Firms in Bali Province.}

The fourth hypothesis (H4) states that the Hardiness Personality weakens the effect of role conflict on the performance of auditors in Public Accounting Firms in Bali Province. The output results show that the interaction coefficient of hardiness with role conflict is 0.095 with $t$ of 0.796 , which is smaller than the $t$ table (1.661). The results of the research analysis showed that $\mathrm{H} 4$ was rejected. This means that the hardiness personality cannot moderate the effect of role conflict on auditor performance. This means that the hardiness personality, which is defined as a collection of personality characteristics that serves as a source of resistance in dealing with stressful life events, cannot guarantee to strengthen or weaken the effect of role conflict in an effort to improve auditor performance. Whether there is a role conflict faced by auditors, it does not make performance increase or decrease. The auditors try to always maintain professionalism in their work even though it is full of role conflicts that occur within them. So in carrying out their audit duties, auditors are professional among their colleagues and can maintain their code of ethics and integrity so that it does not affect the performance of auditors.

\section{Hardiness Personality Weakens the Effect of Role Ambiguity on Auditor Performance in Public Accounting Firms in Bali Province.}

Hypothesis five (H5) states that a high hardiness personality can weaken the influence of role ambiguity on the performance of auditors in public accounting firms in Bali Province. The output results show that the interaction coefficient of hardiness with role ambiguity is 0.533 with a t of 2.142 where the value is greater than the $\mathrm{t}$ table (1.661). The results showed that $\mathrm{H} 5$ was accepted. This means that a high hardiness personality can weaken the negative influence of role ambiguity on auditor performance.

In role theory, it is stated that role ambiguity can arise when the expectations of other parties are not clearly perceived so that a person cannot know his role properly and does not carry out his role as expected from other parties. This can reduce work motivation so that it has the potential to reduce auditor performance.

So based on the results of research analysis, high hardiness personality can weaken role ambiguity in efforts to improve auditor performance. Where according to cognitive theory, personality is the best factor to be used to predict employee performance. Based on the research results, hardiness personality can weaken the negative effect of role ambiguity on auditor performance. This is in line with the research of (Kobasa et al., 1982) which states that the hardiness personality can reduce the detrimental effects of stress by influencing the way individuals think and act when faced with stressful conditions. In addition, the results of this study support (Bartone et al., 2009) which states that someone who has a high hardiness personality will have a strong psychological resistance. The reason is that the individual has a high commitment, great control over his life, and is open to all changes and challenges in life and can deal with stress by turning negative stressors into positive challenges.

\section{Hardiness Personality Weakens the Effect of Role Overload on Auditor Performance in Public Accounting Firms in Bali Province}

Hypothesis six (H6) states that a high hardiness personality can weaken the effect of role overload on the performance of auditors in public accounting firms in Bali Province. The output results show that the interaction coefficient of hardiness with role overload is -0.448 with $t$ of 2.193 where the value is greater than the $t$ table (1.661). The results of the research analysis show that $\mathrm{H} 6$ is accepted, this means that a high hardiness personality can weaken the negative influence of role overload in an effort to improve auditor performance.

The results of this study are consistent with the research of (Burmana et al., 2010) that hardiness personality has a positive effect on performance. Likewise, it is in line with the research of (Cash \& Gardner, 2011) which states that there is a significant positive relationship between hardiness personality and auditor performance. According to (Istiningtyas, 2013) individuals who have a high hardiness personality have the ability to control unpleasant events and give positive meanings to these events so that they do not cause stress to the individual. Social roles describe the rights, duties, obligations and behavior of people who hold certain positions in certain social contexts. Role overload occurs when a person has to carry out a lot of tasks in a limited time. In auditor role overload is usually experienced during busy season, auditors have the potential to experience stress when faced with high working hours and heavy workloads. Because during the busy season the auditor has the responsibility to do field work and find the data needed for audit purposes. Then the auditor must immediately audit the client's financial 
statements and prepare working papers based on the predetermined time. However, a high hardiness personality can weaken the negative effect of role overload on performance because hardy people tend to judge events that occur in life as things that do not cause stress.

Based on the results of the research, individuals with high hardiness personalities will be able to manage stress to face all the problems faced so that efforts to improve auditor performance do not change. This is caused because individuals with high hardiness personalities do transformational copying or change an event that has the potential to cause stress to not cause stress. Hardy people will focus on the problems faced and be able to manage stress to be able to solve these problems so they don't rely on emotions.

\section{Conclusion}

The conclusion in this study is that Workplace spirituality weakens the effect of role conflict on the performance of auditors throughout Bali Province. Second, Workplace spirituality cannot moderate the effect of role ambiguity on the performance of auditors in Bali Province. Third, Workplace spirituality cannot moderate the effect of role overload on auditors' performance in Bali Province. Fourth, the Hardiness personality cannot moderate the effect of role conflict on the performance of auditors in public accounting firms in Bali Province. Fifth, the Hardiness personality weakens the influence of role ambiguity on the performance of auditors in public accounting firms in Bali Province. Sixth, the Hardiness personality weakens the effect of role overload on the performance of auditors in public accounting firms in Bali Province.

\section{References}

Almer, E. D., \& Kaplan. (2002). The Effects Of Flexible Work Arrangements On Stressors, Burnout, And Behavioral Job Outcomes In Public Accounting. Behavioral Research In Accounting, 14, 1-34.

Agustina, L. (2009). Pengaruh Konflik Peran, Ketidakjelasan Peran, Dan Kelebihan Peran Terhadap Kepuasan Kerja Dan Kinerja Auditor. Jurnal Akuntansi, 1(1), 40-69. Retrieved from : https://doi.org/10.28932/jam.v1i1.381

Ashmos, D.P., dan Duchon, D. 2000. Spirituality at Work A Conceptualization and Measure. Journal of Management Inquiry, Vol. 9, No.2, h: 134-145. Retrieved from : http://dx.doi.org/10.1177/105649260092008

Bakar, Z. A. dan Salleh, R. 2015. Role Demands, Work-Family Conflict and Motivation: A Proposed Framework. Global Business \& Management Research, Vol. 7, No. 2, h: 78 - 87.

Baridwan, Z., Gudono., Hambali, Atika J.H., dan Supriyadi. 2016. Dampak Role Conflict, Role Ambiguity, dan Role Overload Terhadap Judgment Auditor. Simposium Nasional Akuntansi XIX, Lampung.

Bartone, P., Eid, J., Johnsen, B., Laberg, J., \& Snook, S. (2009). Big Five Personality Factors, Hardiness, And Social Judgment As Predictors Of Leader Performance. Leadership \& Organization Development Journal, 30(6), 498-521. Retrieved from : DOI: 10.1108/01437730910981908

Burmana, Lovely, B., \& Faturochman. (2010). Pengaruh Kepribadian Tangguh Dan Konflik Peran Ganda Terhadap Kinerja. Universitas Gajah Mada.

Cavanagh, G. F. \& Banduch, M. R. 2002. "Virtue as a Benchmark for Spirituality in Business. Journal of Business Ethics", Vol. 38, pp. 109-177.

Chakrabarty, S., Palaniappan T., dan Ronald D.T. 2006. A Confirmatory Factor Analysis of Reilly's Role Overload Scale. Educational and Psychological Measuremen, Vol. 66, No. 4, h: 657-666.

Chatterjee, M., dan Singhal. 2006. A Person-Organization Fit-based Approach for Spirituality at Work : Development of a Conceptual Framework. Journal of Human Values, Vol.12, No.2, h: 161-178. Retrieved from : https://doi.org/10.1177\%2F097168580601200205

Dane, E. 2011. Paying Attention to Mindfulness and Its Effects on Task Performance in the Workplace. Journal of Management, Vol. 37, No. 4, h: 997-1018.

Duchon, D., dan Petchsawanga, P. 2009. Measuring Workplace Spirituality in an Asian Context. Human Resource Development International, Vol. 12, No. 4, h: 459-468. Retrieved from : https://doi.org/10.1080/13678860903135912 
Dik, B.J., Steger, M.F., dan Duffy, R.D. 2012. Measuring Meaningful Work: The Work and Meaning Inventory (WAMI). Journal of Career Assessment, h: 1-16.

Fisher, R.T. 1995. "Role Stress, The Type a Behaviour Pattern, and External Auditor Job Satisfaction and Performance" (tesis). New Zealand: Lincoln University

Fisher, R. T. (2001). Role Stress, The Type A Behavior Pattern, And External Auditor Job Satisfaction And Performance. Behavioral Research In Accounting, 13, 143-170. Retrieved from : https://doi.org/10.1007/S11104-010-0533-9.

Grant, P., dan McGhee, P. 2015. The Influence of Managers Spiritual Mindfulness on Ethical Behaviour in Organisations. Journal of Spirituality, Leadership and Management, Vol. 8, No. 1, h: 12-33. Retrieved from : DOI : 10.15183/slm2015.08.1113

Handler, C. 2004. The Values of Person-Organization Fit. Advice and How-To's. Diperoleh dari http://www.ere.net/2004/05/20/the-value-of-person-organization-fit/ yang diakses tanggal 18 Agustus 2019.

Hanif, Rheny Afriana. 2013. Pengaruh Struktur Audit, Konflik Peran, dan Ketidakjelasan Peran Terhadap Kinerja Auditor. Jurnal Ekonomi. September, Vol. 21, No. 3.

Hassan, S.M., Hassan, S.S., dan Mir, U.R. 2015. Spirituality and Workplace Stress Management. $A L-A D W A$, h: 44-30.

Istiningtyas, L. (2013). Kepribadian Tahan Banting (Hardness Personality) Dalam Psikologi Islam. Jurnal Ilmu Agama, 14(1), 81-97. $\quad$ Retrieved from http://jurnal.radenfatah.ac.id/index.php/JIA/article/view/463

Jannah, B.S., Baridwan, Z., dan Hariadi, B. 2016. Determinant Of Auditors' Turnover Intention From Public Accounting Firm. Imperial Journal of Interdisciplinary Research, Vol. 2, h: 537-547.

Jimenes, B. M., Munoz, A. R., Hernandez, E. G., \& Blanco, L. M. (2014). Development And Validation Of The Occupational Hardiness Questionnaire. Psicothema, 26(2), 207-214.

Kobasa, S. C., Maddi, S. R., \& Kahn, S. (1982). Hardiness And Health: A Prospective Study. Journal Of Personality And Social Psycholog, 42(1), 168.

Kumar, V.V.A., dan Rai, S. 2012. Five Factor Model of Personality and Role Stress. The Indian Journal of Industrial Relations, Vol. 48, No. 2, h: 341-353.

Marconi, H.R., dan Siegel, G. 1989. Behavioral Accounting. South-Western Publishing Co, Cincinnati.

Milliman., Czaplewski., dan Ferguson. 2008. An Explanatory Empirical Assessment of the Relationship Between Spirituality and Employee Work Attitudes. Paper presented at the Academy of Management Proceedings and Membership Directory.

Mulyono, W.A. 2010. "Hubungan Spiritualias di Tempat Kerja dengan Komitmen Organisasi Perawat di RSI Fatimah Cilacap" (tesis). Jakarta: Universitas Indonesia.

Nazli, M., dan Nor, M. 2011. “Auditor Stress: Antecedents and Relationships to Audit Quality” (tesis), Doctor of Philosophy, Perth : Edith Cowan University. Retrieved from: https://ro.ecu.edu.au/cgi/viewcontent.cgi?article=1404\&context=theses

Olivia, D. O. (2014). Kepribadian Hardiness Dengan Prestasi Kerja Pada Karyawan Bank. Jurnal Ilmiah Psikologi Terapan, 2(1), 115-129. Retrieved from : DOI: https://doi.org/10.22219/jipt.v2i1.1774

Peterson, M.F., dan Smith, P.B. 1995. Role Conflict, Ambiguity, and Overload: A-21 Nation Study. The Academy of Management Journal, Vol. 38, No. 2, h: 429-452. Retrieved from: https://doi.org/10.5465/256687

Piedmont, R.L. 1999. Does Spirituality Represent the Sixth Factor of Personality? Spiritual Transcendence and the Five-Factor Model. Journal of Personality, Vol.67, No.6, h: 985-1013.

Putra, I. G. B. W., \& Ariyanto, D. (2012). Pengaruh Independensi, Profesionalisme, Struktur Audit, Dan Role Stress Terhadap Kinerja Auditor Bpk Ri Perwakilan Provinsi Bali. E-Jurnal Akuntansi, 1(1), 1-18. Retrieved from : https://ojs.unud.ac.id/index.php/Akuntansi/article/view/2019

Riana, I G. 2010. Dampak Penerapan Budaya Tri Hita Karana terhadap Orientasi Kewirausahaan dan Orientasi Pasar serta Konsekuensinya pada Kinerja Usaha dengan Moderator Pembelajaran Bisnis. 
Disertasi. Universitas $\quad$ Brawijaya. $\quad$ Retrieved from : https://jurnaljam.ub.ac.id/index.php/jam/article/view/253

Rizzo, J.R., House, R.J., dan Lirtzman, S.I. 1970. Role Conflict and Ambiguity in Complex Organizations. Administrative Science Quarterly. h:150-163.

Sorensen, J. E., \& Sorensen, T. L. (1974). The Conflict Of Professionals In Bureaucratic Organizations. Administrative Science Quarterly, 10, 98-106.

Suariana, Ketut Dedik dkk. 2014. Pengaruh Gaya Kepemimpinan Dan Independensi Terhadap Kinerja Auditor Eksternal. Ejournal SI AK Universitas Pendidikan Ganesha. Vol. 2, No. 1. Retrieved from : DOI: http://dx.doi.org/10.23887/jimat.v2i1.2338

Tarsidi, D. (2010). Teori Kognitif Sosial Albert Bandura. Bandung: Universitas Pendidikan Indonesia.

Taylor, S. E., Peplau, L. A., \& Sears, D. O. (2009). Psikologi Sosial. Jakarta: Kencana.

Trisnaningsih, S. (2007). Independensi Auditor Dan Komitmen Organisasi Sebagai Mediasi Pengaruh Pemahaman Good Governance, Gaya Kepemimpinan Dan Budaya Organisasi Terhadap Kinerja Auditor. In Simposium Nasional Akuntansi $X$ (Pp. 1-56). Retrieved from: http://pdeb.fe.ui.ac.id/?p=7163

Temaja, I. P. E. A. W., \& Utama, I. M. K. (2016). Pengaruh Profesionalisme, Kepribadian Hardiness, Motivasi Dan Budaya Organisasi Pada Kinerja Auditor Di Kantor Akuntan Publik. E-Jurnal Akuntansi Universitas Udayana, 10(3), 1711-1739. Retrieved from: https://ojs.unud.ac.id/index.php/Akuntansi/article/view/21102

Tenaya, G. A. I. 2007. Analisis Falsafah dan Konsep Akuntansi dalam Perspektif Filsafat Kultur Bali Tri Hita Karana dan Kesadaran Internal Lembaga terhadap Hukum Perusahaan. Thesis. Universitas Brawijaya.

Rahardjo, W. (2005). Kontribusi Hardiness Dan Self-Efficacyterhadap Stres Kerja (Studi Pada Perawat Rsvp Dr. Soeradji Tirtonegoro Klaten). Jurnal Psikologi, 47-57.

Widhiastuti, H. (2002). Studi Meta-Analisis Tentang Hubungan Antara Stress Kerja Dengan Prestasi Kerja. Jurnal Psikologi, 1(1), 28-42.

Wolfe, D. M., \& Snoek. (1962). A Study Of Tension And Adjustment Under Role Conflict. Journal Of Social Issue. Juli, H: 102-121., 102-121. 